That the members of the Association who bave not jet joined a Branch Society may know how to set about it, we subjoin a list of the District Branches, with their presidents and secretaries.

1. Bath axd Bristor Brasch. President, G. Norman, Esq. Secretaries, J. B. Bartrum, Esq., J. Colthurst, Esq.

iI. Dorsershire Branch. President, Charles Cowdell, M.D. Secretary, Henry A. Arden, Esq.

III. Eastary Branch, including Cambridge, Essex, Huntingdon, and Norfolk. President, —_. Secretaries, E. M. Murray, M.B., J. B. Pitt, Esq.

iv. Laxcashire and Cheshire Branch. President, Robert Bickersteth, Esq. Secretaries, John Hatton, Esq., Ellis Jones, Esq.

v. Methopolitax Codsties' Braxch. President, John Forbes, M.D. Secretary, T. Ogier Ward, M.D.

vi. Miduand Counties' Bravch. President, J. C. Williams, M.D. Secretaries, Henry Goode, M.D., T. W. Fearn, Esq., Jos. White, Esq., J. Barclay, M.D., T. C. Simpson, Esq. vil. North Wales Branch. President, Ed. T. Hughes,

M.D. Secretaries, Ed. Williams, M.D., D. K. Jones, Esq.

viri. Suropshire Braych. President, Robert Broughton, Esq. Secretaries, Thomas J. Drury, M.D., John Robert Humphreys, Esq.

ix. South Eastery Braych. President, -. Secretary, Peter Martin, Esq.

x. Socth Westenn Branch. President, P. C. De la Garde, Esq. Secretary, William Dashwood Kingdon, M.D. xi. South Wales Braxch. President, George Gwynne Bird, M.D. Secretary, W. H. Michael, Esq.

xir. Suffolk Brance. President, James Bedingfield, M.D. Secretary, W. P. Kirkman, M.D.

xiIr. West Somerset Bratch. President, S. F. Bridge, Esq. Secretary, F. H. Woodforde, M.D.

xiv. Yorkshire Brancir. P'resident, Charles Chadwick, M.D. Secretary, William Materson, Esq.

This list shows that the greater part of the north of England, and the whole of Scotland aud Ireland, are without Branch Societies. As our numbers are as yet few in Ircland, we cannot in the mean time hope to see Branch Societics established there : but in the north of England, such towns as Newcrstle and Carlisle might become influential centres; and in Scotland several District Branches might without difficulty be erected. For instance, the districts with the most convenient means of access to Inverness, Aberdeen, St. Andrew's, Edinburgh, Glasgow, and Dumfries, might be joined together for the purpose of forming Branches; each of the proposed Branches having respectively as head-quarters one of the leading towns just enumerated.

\section{THE INCOME-TAX.}

Is consequence of a communication from the Metropolitan Counties Branch, made to Dr. Malden through Dr. Cormack, the former gentleman consulted the Central Council at Worcester as to the expediency of a deputation from the whole Assocration waiting upon the Chancellor of the Exchequer. The Central Coumcil are of opinion that such a course is not expedient. They likewise express a desire that the members of the Association be again urged to sign petitions similar to those which have emanated from Worcester and other places. At Leeds, Dr. Chadwick, by means of a circular, obtained about sixty signatures to the same form of petition as that which we printed at p. 219.

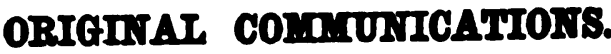

\section{VACCINE LYMPH.}

By J. A. HINGeSTON, Esq., Surgeon.

(Read before the Brighton and Sussex Medico-Chirurgical Society, March 3rd, 1853.)

Whes Jenner broached his opinions concerning Vaccination, in 1798 , his idea was by no means a new one. It took most of his countrymen by surprise, and, for the time, proroked against himself the most unfounded suspicions. But a ray of light had already dawned upon this obscure subject: for, as early as 1770 , nearly thirty years previously, his Majesty, George the Third, had directed the attention of his Parliament to this point in a speech from the throne, in which he mentioned with deep concern the spreading of a fatal disease of an eruptive character among the horned cattle ; and it appears, from the debates which arose on this curious political topic, that the previous existence of the discase was not unknown to some of the members of the House of Commons. Indeed, it had been observed in this country as far back as 1745 ; and its ravages continued as late as 1780 . It was known, likewise, that the same eruptive disease had infested distant parts of Europe ; and that in 1711 , between eighty and ninety ycars before Jenner appeared on the ficld, a pustular disease of this description had broken out in Italy, spread with astonishing rapidity, and in a few months carried off in Piedmont no less than 70,000 head of cattle. Ramazzini, Lancisi, and Lanzani, who describe this epidemic, do not hesitate in regarding it as true variola, or small-pox. Vicq d'Azyr noticed a mild form of the same malady in Picardy. What Jenner saw in 1798 was the remains of this terrible disorder.

These historical facts seem to have been unknown to the discoverer of vaccination, whose genius has shed so lasting a lustre on the title of the British physician. He evidently acted on his own sagacity, the results of which are consequently so much the more valuable, as they are the products of an enquiry the most original of its kind. But while Jenner was thus pursuing his investigations by himself, Dr. Layard, in his second paper read before the Royal Society, mentioned inoculation from cow to cow as being employed to mitigate the disease in these animals, with as much success as inoculation was practised among human beings for a similar purpose. At this period, small-pox was attracting the attention of the world. It was making great havoc every where; men and cattle suffered alike from its ravages; and it was remarked, that during the prevalence of the small-pox, in a given locality, several dairies would become affected with cow-pox at the same time. Horses, as well as cows, suffered from it. Jenner imputed the origin of the vaccine virus to the horse's greasy heels, which he regarded as the real source of the variolous disease in the cow. He lived to correct this erroneous notion, which, however, he had his reasons for entertaining. He remarked the disposition to grease in the horse, occurring chiefly in the spring and autumn, when the cow-pox also occurs in the dairies. He imagined that it was conveyed by the man who groomed the horse to the cow, which he likewise milked, and that in this way the cow became infected with the variolous disease. There was some truth in this supposition. For it is now ascertained that the horse, like the cow, is liable to the variolous discase, and suffers from its attacking that part of the heel, apt to become greasy, where the skin is the thinnest and most favourable to the formation of the vesicles. Hence the pardonable mistake into which Jenner fell. He was never quite satisfied with his own conclusions. His sagacity pointed out to him the want of identity in the two diseases, and some facts led him to suppose at last that the greasy heel might be a modified - rall-pox-an idea not far from the truth. It must have staggered his contemporaries to be told, that from the horse's heels the cow contracted a disease, which, when transferred to man, proved to be a protective against the small-pox; and yet such was 
the fact, although not according to Jenner's interpretation of it.

But this is not all that relates to the variolous discase among cattle; for there is information of a much more recent date than this, and not less interesting in its character. The cows in Bengal suffer from a disease, the same as ours, and the natives call it by a name significant of the word variola. Nr. Mc Pherson, in India, raccinated a child in 18.32 with virus taken from an Indian cow, and the true variolous vesicle was produced. Mr. Wood, at Gowalpara, 1839, produced the same phenomena in the same way; only the symptoms were in his case both very severe and threatening. The intensity of these symptoms might have arisen from an accidental intensity of the disease in the cow; although, when first transferred to man, its effects are usually the more intense, in exact proportion as they approach nearer to their source from the cow.

The suall-pox has been conveyed from man to the cow, just as it has been communicated from the cow to man; and Wr. Waterhouse, of Massachusetts, in a letter to Dr. Jenner, quoted in the P'rov. Med. and siurg. Journal (vol. viii, p. z:3), gives a case in point. This experiment is said to have succeeded in Berlin in 1801. M. Viborg, of Copenhagen, declares he has communicated the disease to dogs, apes, and swine. Dr. HcNichael informed the College of Physicians, in $182 \pi$, that vaccine matter having failed in Egypt, the medical gentlemen were led to institute certain experiments, by which it was discovered, that by inoculating a cow with the small-pox from the human body, fine active vaccine virus was produced, by which children were vaccinatel with complete success. Professor Sonderland, of Bremen, wrapperl cows in sheets in which small-pox patients had slept, and thus succerled in infecting those animals. Gassner hatl already variolated the cow in (iermany, as far back as $18(1 \%$. D). Basil Thicle, of Kasan, in South Russia, succeeded in similar experiments. He appears to have been successful in 1836, at a time when Mr. Ceely was fruitlessly engaged in endeavours to make arrangements for some experiments of his own. In 18:3s Dr. Thiele was again successful. He fixed upon some milch cows, and operated upon them in the spring, miniutaining the cow-house at a temperature of $66^{\circ}$ Falhrenheit. The udder was the part he selected for inoculation, and the animals on which he succeeded were precisely such as Mr. Ceely rejected. Many punctures were rewarded with the result of only a few vesicles. It will he seen, that the chance of suceess is very uncertain, and that different operators, in different quarters of the orlohe, unanimously acknowledge the difficulties with which variolation of the cow from the human subject is surrounded. Perhaps we do not yet know the precise conditions under which it must he undertaken; nor are we yet sufficiently acquainted with the laws of animal poisons, to enter on the investigation with the fucility proper for scientific research. Although more than half a century has elapsed since the time of Jenner. vaccination is hut in its infincy, and calls for the combined energies of pathologists all over the world for its further elucidation and pursuit.

In this country, Mr. Ccely, of Ayleslury, has been distinguished for accomplishing this object. He produced vesicles on the cow, from which he raccinated sereral hundred patients, who exhibited all the phenomena of vaccination in the most complete degree: there was no attendant eruption, nor anything else that could lead him to suspect that he had not in this manner propagated the genuine variola vaccina. This virus was tested by other practitioners, whose experience in vaccination left no room for doubting the just weight of their testimony; and these gentlemen affirmed that it produced regular vesicles, exactly like those so beautifully delineated in Jenner's first publication. Others, who saw these vesicles without being aware from whence the virus that produced them had been drawn, acknowledged their correctness. Nothing could be more conclusive than experiments such as these, which, in a practical point of view, established the identity of the two discases. The cow had been inoculated with virus taken from man, and the virus taken from the cow had produced the usual phenomena of vaccination. The fact was self-evident, and reasoning was at an end.

Moreover, since Mr. Ceely vaccinated the cow from man, it has been effected at Passy, near Paris; and the lymph found there among the cows, in 1836 , has since then been passed through the animals again; and this is called retroinoculation. The human lymph, when transmitted in this manner, loses some of its activity, rises later, ancl produces smaller vesicles; but it recorers its activity by successive inoculations on man again. This, again, is one of those delicate tests, which speaks for itself.

It would seem, then, that cow-pox and the smallpox are identical discases, and that the vaccine disease is not the preventive of small-pox, but the small-pox itselfthe substitute, rather than the antidote; so that the person who has been raccinated, has had the small-pox in a mild form. Cattle are liable to the small-pox, which co-exists with the same disease as an epidemic among men. When severe in cattle, it produces by inoculation a similar sererity in man; and, as man way have it from the eow, so the cow may have it from man. When a mild small-pox is taken from the cow, and conveyed hy raccination to the human hody, it produces a mild disease, such as Jenner first described it; and proves to be, in the greater number of instances, an effectual protective agraiust the infection of small-pox. No one of any experience can pretend to contradict this sulsstantial statement of facts ; nor dare to deny that raccination, properly performed, is a positive safeguard against the small-pox pestilence. This datum is irrefragible, and forms a fixed point in the history of medicine, from which a new era commenees.

Subserquently to Jenner, nothing new has been added to his original discoveries. What he saw, we continue to see, such as he described it. The inflamed point of the third day; the small pustule of the sixth; the areola, sometimes extensive and erysipelatous, of the cighth; the dark scal of the twelfth; and the black, dry crust, of the fourteenth, are the same now as they were then. He said the rirus was most potent while it was lymphatic, that is, on the seventh day; and so it now is. He said that deep incisions in vaccinating, or inoculating, werc injurious ; and that puncturing or wounding the cuticle alone was the safest and most effectual mode of performing this little operation; and we find it to be so. He remarked, that cow-pox was not infectious, but only contagious, which every one is aware of. He considered that the areola or inflammation took place sooner in cases disposed to reject the specitic action of the virus; and, in second vaccinations, we find the inflanmation rising on the sixth day, instead of on the eighth. In his time, when persons performed vaccination with imperfect virus, it of course failed as a protective agent ; and what happened then, happens now, and is one of the reasons why the public have lost their implicit confidence in its protective power. He declared, that vaccine virus loses none of its characteristic properties by passing through successive renerations ; and bis declaration has proved itself correct ; for, if it has failed in virtue or aspect, the failure is owing, not to successive transmissions, but either to the virus having hicen badly selected, or to the constitution from which it was taken being disordered at the time. There is a proper time, as well as a proper state of health, in the progress of the vesicle, when the lymph is ripe and active ; but in default of this, it proves effete or immature. Jenner stated the time for taking the lymph to be from the fifth to the eighth day, just before the areola forms; and what he stated is true. Dr. Bryce, of Edinburgh, advised testing the efficacy of each vaccination by a second, performed a few days after the first. This is a beautiful illustration of the secondary vaccination running through its stages with accelerated speed : it is called "Bryce's test". The vesicle from which lymph is taken ought to be a perfectly correct one ; otherwise, failure is likely to ensue in propagating virus with it. A deviation in the charncter of the cow-pox may be perpetuated by vaccinating from a devious vesicle. It is to be regretted, that sufficient attention 
is not always paid to a contingency so important as this. The presence of eruptive diseases modifies the true character of the vesicle; and of these cutaneous affections, herpes is said to be the worst. One vesicle ought never to be touched, but left to run its course unmolested. It serves as a criterion of the validity of the vaccine virus. The presence of a cicatrix cannot be relied on as a proof of the vaccination being protective, although its absence is very nearly proof positive against it. A second vaccination will sometimes take effect, close by an old cicatrix of the most approved appearance. Idiosyncracies are beyond our calculation, and there is no end to them. Some resist vaccination or inoculation at one time, and then take it at another; others take the natural small-pox a second time; some never take it at all ; some take it after inoculation; and others, again, have taken it as often as three times or more in the course of their lives. In some persons, the protective power of vaccination is lost or weakened by age; in others, it is never lost; and in very few, it is not even the slightest protection. These anomalies form no ground of argument either for or against its efficacy as a protective agent, but remain to be considered apart as individual elements, the relative values of which are unknown.

We are now prepared to consider the importance of the experiments performed by Mr. Ccely, of Aylesbury, and Mr. Badcock, of Brighton, both of whom have given their minds to this inquiry. It does not appear that any others have done the same as they have, in this country.

Variola was long known in the Vale of Aylesbury, as a disease infesting the cows in the autumn, winter, and spring of the year. Sometimes it would be generally prevalent, but at other times there were only solitiry cases. Forty years would elapse without its making its appearance in a particular dairy ; while, in a neighbouring farm, it would break out as often as twice in the space of five years. A fresh cow might bring it, or it showed itself no one knew how. Milch cows alone were not the suljects of it, neither were the uplands or lowlands its favourite haunts. It was milder in some seasons than in others, and more severe in one animal than in another. The teats of a healthy cow would become tender and hot, and the milk would diminish. Vesicles formed on the udder, around the base of the nipple : their numbers would vary, but pendulous udders had the most. The dark red and spotted cows suffered more than those of a lighter colour. 'The attack lasted four or five weeks. Some of the animals escaped the disease, though it was highly contagious. The vesicles rose up in size from that of a pea to a horse-bean. They were lroken in milking, which left an irritable ulcer. Wach vesicle had a central depression, with a hard margin, and, if it were opened or torn, a thin amber-coloured tluid oozed out. Then a dark brown oval crust formed. On the eirghth day, an areola of inflammation appeared, chiefly discernible in the light cows. Lymph burst from under the crust on the eleventh day, and on the fourteenth there was a decidedly black scal. The peculiar odour of small-pox attended the last stages of the eruption. The black crusts hung about till the third or fourth week. Twenty-one days completed the disease ; the last, or crusted stage, being the most protracted.

In cows, the malady is modified by circumstances not incidental to man. The rough handling of the milkers breaks the vesicles, and disturbs the natural order of the disease; while, by milking one cow after another, they go on vaccinating and re-vaccinating the whole stock, until the several phenomena, usually so distinct when left to themselves, are all mingled in one. Thus, the primary and secondary vaccination-Jenner's vesicle and Bryce's test-are coupled in the same animal; broken vesicles are blended with whole ones; the first stage is conjoined with the last ; old crusts and fresh lymph are huddled together on a single udder. Besides, the cows are liable to spurious pocks, which are not a little puzzling ; for the cow-pox is not so frequent an occurrence in the dairy as to render it an easy thing to be decided on at a glance, without running the risk of mistaking a spurious eruption for the genuine disease. And, indeed, milkers catching the false pocks, fancy themselves vaccinated, and only discover their error by being unexpectedly seized with the small-pox, from which they had imagined themselves exempt.

Mr. Ceely considers mere contact sufficient for vaccination, without any visible abrasion of the skin. The milkers contract the disease simply from handling the teats while milking, and suffer from it on their hands and face: the men, between their fingers, on the back and palms of their hands, on their eyelids, cheeks, and foreheads ; the women, wearing short sleeves, on their forearms and wrists, from contact with their own hands, or the animal's body. Abscesses and sinuses sometimes follow these eruptions, as well as axillary swellings. Occasionally, those who have already been vaccinated, re-vaccinate themselves from the cow; and the symptoms of the latter are sometimes more distressing than those which they remember of their former vaccination.

There is some difficulty in procuring the primary lymph, owing to the difficulty of finding a cow properly infected with a vaccine vesicle just ripe for transfer; for the vesicle must not have been broken, nor must the matter it contains be taken away earlier than the fifth, nor later than the ninth day. And when the primary lymph has been at length procured from the cow, it is not always quite so easy to vaccinate human beings with it; because it happens that morbid poisons do not easily pass from animals of one class to those of another, as from the cow to man, and the converse. Man, indeed, more readily receives the morbid poisons of the lower animals, than they do of him; but even this reciprocal susceptibility varies so much, and is open to so many exceptions, that nothing certain can be said about it.

Mr. Ceely owns (Prov. Med. and Surg. Jourin. vol. viii, 1840 , p. 343, ) that one half of his attempts to vaccinate with primary lymph failed, although vaccination from the human subject succeeded in the same persons; or else, that, if he did succeed, his success did not prevent secondary vaccination from taking effect. A small number vaccinated with primary lymph, presented vesicles of the highest degree of beauty and correctness, after more or less delay; but even then not every one of the punctures took effect. Sinilar results ensued with lymph taken from the hands of the milkers, or from early removes of the primary lymph. The symptoms of primary vaccination direct from the cow, are more intense and protracted than in that from man to man. Some patients need preparation before being vaccinated with primary lymph, as they used to be for inoculation for small-pox. Vacciue lymph becomes milder by transmission from mail to man : more humanized, though its generic character and properties remain the same. Constitutional disturbance is not necessary for the efficacy of the vaccine virus, for the finest vesicles arise with the smallest amount of disturbance to the general health.

Unlike man, the cow may be vaccinated (not inoculated, but vaccinuted) without abrusion of the skin ; contact alone being all that is requisite for effecting it.

It is a most singular property of the vaccine virus, that, by having passed through the economy of a lower animal, it comes out with nothing more of the small-pox pestilence in it than exactly so much as is innocuous as a morbific, and yet thoroughly efficient as a protective agent. 'This transmutation of an infectious into a contagious disease, is as remarkable as it is inexplicable, and stimulates our curiosity to the last degree of earnest inquiry and research.

There is a good denl of expense attendant on inoculating cows with the small-pox, as well as a great deal of difficulty and uncertainty in obtaining the required results. Ubstacles such as these deter others from entering ou expcriments likely to clear up points that still are doubtful; but they enhance the value of the data already given, and reflect the greater credit on those who have alone stepped forward to explore the question.

Mr. Badcock, of Brighton, has gone over the same ground as Mr. Ceely. In his opinion, the cows used to suffer from 
the small-pox much more frequently years ago than they do now, since vaccination has become general, and helped in diminishing the disease. His attention was first drawn to this subject by the frequent occurrence of small-pox ufter vaccination. He himself was attacked by it ; and it was this misfortune which led him to doubt the efficacy of the vaccine lymph then in vogue. He looked out for cow-pox among the cows, but found the malady, such as Jenner described it, scarcely known in the dairies. He then inoculated a cow with the small-pox virus, in 1840. A pamphlet, published in 1807 , by Mr. Pruen, entitled $A$ Comparative sketch of the Variolous and Vaccine Virus, first awakened his mind to this idea. He invited several medical men to inspect the vesicle which he had thus produced. on the animal, and they agreed as to its genuine character. By means of matter taken from this cow, he vaccinated one of his own children, and produced the true vaccine vesicle. His expectations were answered. Other children were next vaccinited with the matter taken from his own child, as well as with that from the cow; and the results were equally favourahle. More than twenty medical men inspected his child's arm during the progress of the vaccine vesicle, and many of them requested supplies of lymph from it, in order to ascertain its effects on others under their care. It did not disappoint any one of them. It was beyond question, that Mr. Badcock had succeeded in engendering and propagating a fresh supply of primary vaccine virus.

Soon afterwards, Mr. Ceely's similar experiments became known to him, which encouraged him to persevere in his pursuit. Residing in a populous town, where the small-pox is not unfrequent, and possessing cows of his own, which he appropriatcd to this particular purpose, he was enabled to inoculate some of these animals; and, out of three hundred attempts, at different times, on two hundred cows, he succeeded in infecting about thirty of them with the small pox virus. The result of the operation is very uncertain, The most susceptible are those with calf. He never succeeded on a barren cow : he was once successful on a cow-calf, three weeks old.

Mr. Badcock has vaccinated upwards of twelve thousand children himself, with matter drawn from this source. The medical men of Brighton have frequently used the same matter, as is very well known. During one month, Mr. Badcock furnished above eight hundred charges in this town alone, besides more which he distributed to the medical practitioners resident elsewhere. It docs not appear that any of the medical men have ever doubted the genuineness and efficacy of the lymph thus obtained. Children, after being vaccinated with it, have slept in the same bed with those sick of the small-pox, without catching the disease. Mr. Ceely, of Aylesbury, submitted it to the very trying test of subsequent inoculation with the small-pox, but without effect. 'The parish surgeon of Brighton has continued his vaccination from a stock of lymph originally drawn from one of Mr. Badcock's cows a long time since, nor would he willingly give it uj. From those competent to form a just estimate of its value, it would appear that there is good ground for believing this new vaccine, or modified smallpox, to be superior to the old in the intensity of its action as well as in its certainty as a protective agent.

Mr. Badcock, who has watched its progress and effects with the closest attention, is convinced of its superiority. As far as his observation has extended, he has not known of a single failure. But then he is a clever vaccinator, and never neglects any one of those rules so indispensable to success, and to the omission of which may be imputed most of the miscarriages alleged against vaccination. When revaccination is practised, the primary lymph, such as Mr. Badcock's, is of the utmost value, on account of the intensity with which it acts, and the certainty of its taking effect, supposing the constitution unprotected by previous vaccination.

Against vaccination with primary lymph, it has been charged that it causes extensive inflammation, sloughs, etc.: and cases are quoted in illustration. But the same objections may be urged against vaccination with Jenner's lymph, and even against inoculation with the small-pox virus. The same matter which vaccinates one child in the best and safest manner, will, in the same family, give rise in another child to disagreeable, if not alarming symptoms. But these cases are rare, and may be regarded as exceptions depending on peculiarities of health, over which we have no control. The scrofulous habit is most obnoxious to penalties of this sort : and the presence of cruptive diseases, or of general ill-health, for the time being, contraindicate the propriety of vaccination, as all the world is aware of. No one ever maintains that the introduction of vaccine virus into the system is something to be desired; on the contrary, it is, at the best, but a matter of choice between two evils-the lesser one, or cowpox, which is harmless, and the greater, or small-pox, which is always hideous, and sometimes fatal.

The old lymph of Jenner's is supposed to have become less potent, from the length of time it has been in use, and therefore the less to be relied on. A new lymph, producing the genuine vaccine vesicle, has been obtained from the cow afresh, by previously inoculating the animal with human small-pox; and this new lymph, thus procured, is believed to be more efficacious than that of Jenner's original stock. The question is not easily settled; but the amount of combined evidence and experience speak loudly, as far as they go, in favour of the new lymph thus recently obtained.

Mr. Badcock's experiments, next to those of Mr. Ceely's, are of the highest practical importance. In this country they stand alone. Not many are likely to start up as rivals in the same pursuit; for the task involves more trouble, time, expense, and disappointment, than most people are willing or able to incur. Remuneration there can be none. The lore of science alone can be the motive: and yet it is evident that, in the execution of a work, costing the continual outlay of capital, something more substantial than the best individual zeal is clearly requisite. What yields a common advantage might be maintained at a common expense. It is an undertaking that merits the general attention of the nation, and is not only not beneath the serious consideration of the legislature, but is one of those chief items of sanitary reform that concern the millions of this vast empire.

Whatever may be the cause assigned, the decline of the old lymph is acknowledged. It has been pointed outby competent observers in every quarter of the globe. In a letter to Dr. Golding Bird, in the month of December 1851, Mr. Ceely remarks : "that vaccine lymph can be and has been deteriorated by a varicty of causes, is indisputable. The fact is notorious in India (Quarterly Journal of the Calcutta Medical and Physiological Society, April 19th, 1837) ; it has been proved in Paris (Notice sur le Cove-pox découvert $\dot{u}$ Pas:y, par M. Bousquet, 1836); it has been demonstrated in London (Report on Sinall-pox, by (the late) Dr. Gregory, Med. Gaz. Feb. 24th, 1850). That it may be rendered wcak and inefficient by accident or carelessness, by ignorance, or something worse, every experienced vaccinator will readily allow." The inefficiency of vaccine has manifested itself in America. Application was made to Mr. Badcock for a fresh supply, and his new lymph was introduced into the United States by Dr. Coale, of Boston, where it was so much approved of by Dr. Clarke and the other medical officers of the Massachusetts General Hospital, that it has entirely superseded the old lymph previously employed at that institution.

In the foregoing remarks, my object has been to bring the subject of vaccination before the notice of the medical profession My materials have been drawn from various sources; and, though I have not quoted my authorities, yet, as I disclaim anything like originality on my part, every one will feel himself entitled to appropriate whatever is properly his own. I have neither the intention nor the wish to be anything else than a copyist. The inquiry is a deeply interesting one, and is becoming more and more 
so every day. It is already attracting the attention of the legislature. In the army, it is an indispensable requisite; in private practice, it is of paramount importance, because the validity of raccination depends on the skill and care of the vaccinator.

Brighton, March 16th, 1853.

\section{SKETCH OF THE CHOLERA EPIDEMIC WHICH PREVAILED AT SOUTHAMP'TON IN THE SUMMER OF 1849.}

I.y W. S. OKE, M.D., Senior Physician of the Royal South Hants Infirmary.

(Read before the Southampton Medical Society, Ficb. 18t, 1853.) BEFORE entering upon the more immediate subject of this paper, I deem it right to make a few introductory remarks upon the town in which we live.

ToponRAPIIY. Southampton is situated in $50 \mathrm{deg} .54$ min. 34 sec. N. lat., and 37 min. 7 sec. W. long. It occupies a tongue of land, about a mile in breadth, abutting towards the S.W., upon a small inlet of the sea, called the Southampton Water, which flows and ebbs N.W. and S.E. It is bounded on the east by the Itchen river; on the west, hy a bay of the inlet; and on the north, by a wooded common, gradually rising to an elevation of 234 fect. It is, for the most part, built upon a bed of gravel, beneath which is argillaceous deposit. The sea in its ebb, especially at spring tides, recedes to a considerable distance, exposing an extensive surface of muddy sand, the appearance of which has been considered by some metropolitan physicians to be a prima facie evidence against the salubrity of the town ; but this chirge is completely disproved by the fact, that the exhalations at low water by the solar rays have never been productive of any endemic febrile disease whatever, whether intermittent, remittent, or continued. Indeed, the flow of the tides, and the rentilation almost always accompanyiug it, will probably ever prevent such a result ; in confirmation of which, there are not many towns in the United Kingdom, with an equal amount of population, where so few cases of such fevers are registered. It is true, that the registrar's books show a high rate of mortality in its crowded districts, especially in the parish of St. Mary; but it is clear that this has not been caused by malarious exhalation at ebb-tides, for the same registry shows that, in the less crowded districts, parts of which are also contiguous to the water, the rate of mortality is not higher than that of some of the most healthy towns in Great Britain. The cause, therefore, must be sought for elsewhere; and doubtless it may be found in the rapid increase of population which of late years has taken place, from the extensive establishments connected with railways, docks, and steam-navigation companies.

$$
\text { POPLLATION. }
$$

In 1801, the population was 7,62

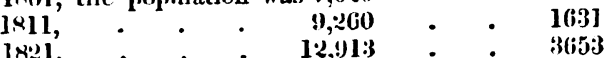

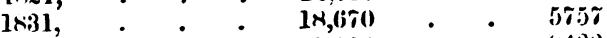

$$
\begin{aligned}
& 1841, \cdot \cdot 2 \pi, 103 \cdot 5433 \\
& 1851, \cdot 0.34,0922 \quad 0089
\end{aligned}
$$

It will thus be seen that, in a cycle of twenty years, the population of the town has heen nearly doubled; and, taking the parish of St. Mary alone, the increase is still more remarkable; the amount in 1831 being 8,530 , and 21,012 in 1851! These statistics of the population have been introduced to account also for the great difference betwixt the two choleric epidemies which invaded Southampton, as regards both their extent and mortality.

Origin and Progress of Cholera. The pestilential cholera of the nineteenth century* commenced at Jessore,

- That the very same disease was known as early ax the first century, the following quotation from Celsus will clearly show:-" P'rimoque facienda mentio est cholerx; quia commune id stomachi atque intestinorum vitiun videri potest. Nam simul et dejectio et vomitus est: præteryue lac inflatio est, intestina tomnentur, bilis supr' infrapue erumpit, primum aquæ similis, deinde ut in ea recens caro lota esse; videatur, interduin alba, nonnunquam a populous town in the Delta of the Ganges, in 1818, from which point it spread in every direction throughout Indie and Asia, confining itself to that quarter of the globe till 1831, when it took a north-western course through Russia Poland, Austria, and Prussia ; ravaging Vienna, Berlin, and Hamburgh, in its way to Great Britain, where it made its Hamburgh, in its way therland on the 26th of October, first appearance at Sunderland on the 26th of October, 1831 ; but no cases were reported in London till the middle
of February $1832 .^{*}$ The disease first invaded Southampton in the summer of 1833 . As it was ushered in by a case which terminated fatally in a few hours, a great panic was caused, espccially as cholera prevailed in many parts of the kingdom. The patient was a poor girl of the age of puberty, residing in Russell Street, St. Mary's. Her friends. attributed the attack to a meal of cockles, which might indeed have been an exciting cause; but the symptoms were too characteristic to be mistaken. Every attention was. paid which the urgency of the case required; and her medical attendant remained at her bed-side till she sank medical attendant remained at her ved-side till shessant vomiting and purging of rice-water evacuations. The bedding, bed-clothes, and everything that could be the means of propagating the disease, were burnt by the order of the municipal authorities : and the house was cleansed and whitewashed. Whether from these precautions or not, the disease did not spread; nor did it prevail to any extent in other parts of the town; so that the number of cases were not probably more than twelve, nor the deaths above four. The population at this pcriod may be estimated at about 20,360. From this time the town was free from cholera till the year 1849 , when it was again visitcd by the disease, and far more severely than before. The second epidemic commenced on the 17th of June, and terminated on the 2lst of September, at which period the population had increased 25.78 per cent., and amounted to about 30,000.

Meteorological ReMarks. During the prevalence of the disease, Dr. Drew's Meteorological Register gives the following results; and the public are much indebted to this gentleman for establishing and superintending a register at Southampton, which, for its accuracy and completeness, is

\begin{tabular}{|c|c|c|c|c|c|c|}
\hline \multirow{2}{*}{ June } & \multicolumn{4}{|c|}{ Thermometer. } & \multirow{2}{*}{$\begin{array}{c}\text { Adiopted } \\
\text { Mleun. } \\
60 \cdot 1\end{array}$} & \multirow{2}{*}{$\begin{array}{l}\text { Monthly } \\
\text { linge } \\
45 \cdot 1\end{array}$} \\
\hline & $\begin{array}{l}\text { Date. } \\
\text { :4th }\end{array}$ & $\begin{array}{l}\text { Itighest. } \\
\text { di.06 }\end{array}$ & $\begin{array}{l}\text { Date. } \\
\text { 11th }\end{array}$ & $\begin{array}{c}\text { Lowest. } \\
\mathbf{4}: 5 \cdot 5\end{array}$ & & \\
\hline & lith & Nis. & 1st & $42 \cdot 6$ & $60-3$ & \\
\hline ust & Sth & $77 \cdot 6$ & 1\%th & $41 \cdot 6$ & $60 \cdot 7$ & 36 \\
\hline & 5th & $76 \cdot 6$ & 19th & $37 \cdot 6$ & $56 \cdot 6$ & 39 \\
\hline
\end{tabular}
probably equal to any in the kingdom.

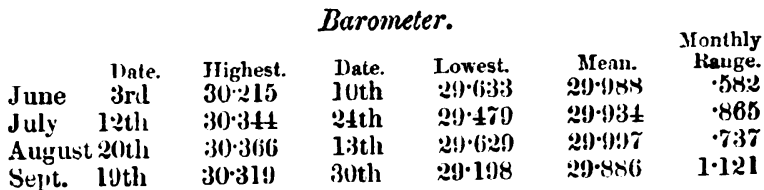

N.B. On the 11 th of July, the thernometer in the sun, at $:$ P.M., was 1:20; in August, 104.

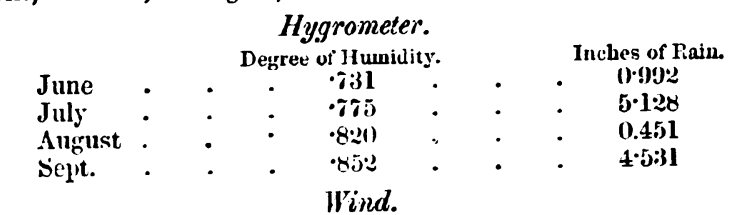

\begin{tabular}{lcc}
\multicolumn{2}{c}{ Furce-6 signifjing a Gale. } \\
June & $\cdot 1$ & 4 th and 8 th. Thunder. \\
July & $\cdot 3$ & 26th. 'Thunder. \\
August & $\therefore 2$ & 1lth and l2th. Lightning. \\
Sept. & $\cdot 2$ & lst. Thunder and lightning for 2 hours
\end{tabular}

The principal points to be noticed in the foregoing results are, 1st, that the temperature of the atmosphere was

nigra vel raria Firgo eo nomine morbum hunc Xoגépay Groci nominanigra vel raria fro co manus que contrahuntur, urget sitis, suimu deficit quibus .. ese si subito quis moritur.... Si post pupressam choleram febricula manet, glvun ducl necessarium est: tum cibis vinoque uteudum est." - Liber iv, ch. $\mathrm{xi}$.

- vinoque uteudum esh" 